\title{
Suitability of flat bedded salt formations in Germany as the site for a repository for heat-producing radioactive waste
}

\author{
Till Popp, Ralf-Michael Günther, and Dirk Naumann \\ Institut für Gebirgsmechanik GmbH (IfG), Friederikenstraße 60, 04279 Leipzig, Germany \\ Correspondence: Till Popp (till.popp@ifg-leipzig.de) \\ Published: 10 November 2021
}

\begin{abstract}
The search for a site of a final repository for highly radioactive waste in Germany was renewed when the Site Selection Act (StandAG) came into force in 2013. In Germany the development of concepts for a final repository and safety analyses for a repository in a salt dome was prioritized for many decades, whereas repository concepts in clay and crystalline rock were first considered only two decades ago. The aim of a comparative site selection procedure is to find a site before 2031, which provides the best possible safety for the enclosure of highly radioactive waste over a time period of 1 million years.

The fundamental safety-related consideration is the enclosure of toxic waste in a so-called containment effective geological area (ewG). The main aspect of a long-term proof of safety is logically the systematic proof of safe long-term enclosure of the deposited waste. The approach developed within the framework of appropriate research projects (e.g. Eickemeier et al., 2013) is essentially based on the proof of geotechnical integrity of the ewG as the fundamental geological barrier as well as the geotechnical barriers.

Due to their unique characteristics, including imperviousness and plastic deformability, salt rocks have been used for decades in Germany and worldwide in mining and especially for energy storage.

Whereas halite in salt domes (type steep inclined salt) is distributed particularly in northwest Germany, flatly deposited salt rock (type flat bedded salt) dominates in middle Germany and salt pillows (type salt pillows) in parts of northeast Germany. Both types of "bedded salt" widely reflect in their lateral extension sedimentationrelated deposition conditions, apart from diagenetically related alterations.

Beginning with the presentation of the host rock-specific boundary conditions of the various rock salts, this article focuses on the appropriate procedures for the proof of integrity of the geological barrier rock salt, based on the available experiences, corresponding reference studies and analogous examples. In the results it is shown that repository concepts in bedded salt formations and especially in the constellation of salt pillows provide substantial safety-related advantages due to a site-specific multibarrier system with alternate deposition of salt and saliferous clay as well as an intact overlying rock covering.
\end{abstract}

Kurzfassung. Seit 2013 hat in Deutschland die Standortsuche für ein Endlager für hochradioaktive Abfälle mit Inkrafttreten des ersten Standortauswahlgesetzes (StandAG) neu begonnen. Viele Jahrzehnte lang wurde in Deutschland die Entwicklung von Endlagerkonzepten und Sicherheitsanalysen für ein Endlager in einem Salzstock priorisiert, während Endlagerkonzepte für Tongestein und kristallines Gestein erst seit 2 Jahrzehnten berücksichtigt werden. Zielstellung eines vergleichenden Standortauswahlverfahrens ist, bis 2031 einen Standort zu finden, der für einen Betrachtungszeitraum von 1 Mio. Jahre die bestmögliche Sicherheit für den Einschluss hochradioaktiver Abfälle bietet.

Sicherheitstechnischer Grundgedanke ist dabei der Einschluss der Schadstoffe im sog. einschlusswirksamen Gebirgsbereich (ewG). Im Mittelpunkt eines Langzeitsicherheitsnachweises steht folgerichtig der systematische Nachweis des langfristig sicheren Einschlusses der endgelagerten Abfälle. Die im Rahmen entsprechender Forschungsvorhaben entwickelte Vorgehensweise (z.B. Eickemeier et al., 2013) basiert wesentlich auf dem 
Nachweis der geotechnischen Integrität des einschlusswirksamen Gebirgsbereichs, als wesentlicher geologischer Barriere, sowie der geotechnischen Barrieren.

Aufgrund ihrer einzigartigen Eigenschaften, u. a. Dichtheit und plastische Verformbarkeit, werden Salzgesteine in Deutschland und weltweit seit Jahrzehnten bergbaulich und insbesondere für die Energiespeicherung genutzt.

Während Steinsalz in Salzstöcken (Typ: steile Lagerung) vor allem in Nordwestdeutschland verbreitet ist, dominieren in Mitteldeutschland flach gelagerte Salzgesteine (Typ: flache Lagerung) sowie in Teilen Nordostdeutschlands Salzkissen (Typ: Salzkissen). Beide Typen der „flachen Lagerung“ („,bedded salt“) spiegeln in ihrer lateralen Erstreckung - abgesehen von diagenetisch bedingten Veränderungen - weitgehend sedimentationsbedingte Lagerungsverhältnisse wider.

Ausgehend von der Darstellung der wirtsgesteinsspezifischen Randbedingungen der verschiedenen Salzgesteine fokussiert dieser Beitrag auf die entsprechenden Vorgehensweisen für den Integritätsnachweis des geologischen Barrieregesteins Salz auf Basis vorliegender Erfahrungen und entsprechender Referenzstudien sowie von Analogbeispielen. Im Ergebnis wird gezeigt, dass Endlagerkonzepte in der flachen Lagerung in der Konstellation Salzkissen aufgrund eines standortspezifischen Multibarrierensystems mit einer Wechsellagerung von Salz und Salztonen sowie einem intakten Deckgebirge erhebliche sicherheitstechnische Vorteile bieten.

\section{References}

Eickemeier, R., Heusermann, S., Knauth, M., Minkley, W., Nipp, H.-K., and Popp, T.: Preliminary Safety Analysis of the Gorleben Site: Thermo-mechanical Analysis of the Integrity of the Geological Barrier in the Gorleben Salt Formation, WM2013 Conference, 24-28 February 2013, Phoenix, Arizona, USA, 13307, 2013. 